\title{
PELUANG MINUMAN KOMBUCHA SEBAGAI PANGAN FUNGSIONAL
}

\section{OPPORTUNITIES OF KOMBUCHA DRINKING AS A FUNCTIONAL FOOD}

\author{
Aniswatul Khamidah ${ }^{1)}$ dan S. S. Antarlina ${ }^{1)}$ \\ ${ }^{1)}$ Balai Pengkajian Teknologi Pertanian Jawa Timur \\ Email: aniswatul.bptp@gmail.com
}

\begin{abstract}
ABSTRAK
Kebiasaan masyarakat Indonesia dalam mengkonsumsi teh, memberikan peluang besar dalam pengembangan kombucha. Kombucha merupakan minuman dari teh yang difermentasi dengan mikroorganisme, yang mempunyai lebih banyak manfaat dibandingkan dengan teh biasa. Aktivitas mikroorganisme selama fermentasi akan menghasilkan berbagai senyawa yang bermanfaat bagi kesehatan, di antaranya adalah senyawa fenolik. Semakin tinggi senyawa fenolik yang dihasilkan maka semakin tinggi pula aktivitas antioksidannya. Selain itu kombucha mengandung senyawa organik yang bermanfaat bagi tubuh sehingga sangat berpotensial sebagai pangan fungsional. Makalah ini bertujuan untuk memaparkan peluang kombucha sebagai pangan fungsional, manfaat kombucha, nilai gizi, jenis mikroba yang berperan, proses pembuatan kombucha serta aktivitas antioksidan minuman kombucha dari berbagai komoditas seperti rosela, daun salam, daun jambu, daun sirih, daun sirsak, daun kopi, daun teh, bawang tiwai, teh hijau, teh oolong, daun coklat, daun mangga dan daun tin. Diharapkan minuman kombucha sebagai alternatif diversifikasi pangan fungsional yang dapat bermanfaat bagi kesehatan dan meningkatkan immunomodulator.
\end{abstract}

Kata kunci: fermentasi; kombucha; pangan fungsional

\section{ABSTRACT}

The habits of the Indonesian people in consuming tea, provide a great opportunity in the development of kombucha. Kombucha is a beverage made from fermented tea using microorganisms, which has more benefits than original tea. Microorganism activity during fermentation will produce various compounds that are beneficial to health, including phenolic compounds. The higher the phenolic compound produced, the higher the antioxidant activity. In addition kombucha contains organic compounds that are beneficial to the body so it is very potential as a functional food. This paper aims to explain the opportunities of kombucha as functional food, the benefits of kombucha, nutritional value, the type of microbes that play a role, the process of making kombucha and the antioxidant activity of kombucha drinks from various commodities such as rosella, "salam" leaves, guava leaves, "sirih" leaves, soursop leaves, coffee leaves, tea leaves, onion tiwai, green tea, oolong tea, cocoa leaves, mango leaves and tin leaves. Kombucha drinks are expected as an alternative to functional food diversification that can benefit health and enhance immunomodulators.

Keywords: fermentation; functional food; kombucha 


\section{PENDAHULUAN}

Aktivitas minum teh merupakan kebiasaan yang sudah lama dikenal masyarakat Indonesia. Teh yang difermentasi menggunakan mikroorganisme akan memberikan variasi cara dalam mengkonsumsi teh. Teh yang difermentasi yaitu kombucha mempunyai nilai gizi lebih tinggi dan bermanfaat bagi kesehatan dibandingkan dengan teh biasa. Kombucha mempunyai bentuk massa gelatinosa atau menyerupai agar-agar biofilm putih yang mirip nata de coco hanya medianya yang berbeda. Secara bersamaan, bakteri dan ragi bersimbiosis memanfaatkan nutrisi yang terkandung dalam teh manis menghasilkan miofibril berlapis. Lapisan terbaru berada di lapisan paling atas dan mengambang di permukaan teh (Miranda, et al., 2016).

Aktivitas mikroorganisme selama fermentasi menghasilkan berbagai senyawa yang bermanfaat bagi kesehatan, di antaranya adalah sejumlah vitamin, mineral, enzim serta senyawa fenolik. Semakin tinggi senyawa fenolik yang dihasilkan maka semakin tinggi pula aktivitas antioksidannya. Selain itu kombucha mengandung senyawa organik yang bermanfaat bagi tubuh sehingga berpotensial sebagai pangan fungsional (Wistiana dan Zubaidah, 2015).

Substrat media kombucha yang biasa digunakan adalah teh dari daun Camellia sinensis, tetapi sekarang ini berkembang pembuatan kombucha menggunakansubstrat lain. Dengan beragamnya media kombucha yang digunakan, akan semakin memperkaya diversifikasi pangan. Demikian juga nilai gizinya akan semakin beragam.

Makalah ini bertujuan memaparkan peluang kombucha sebagai pangan fungsional, faktor pembatas yang mempengaruhi pertumbuhan mikroba, jenis mikroba yang berperan serta senyawa yang dihasilkan, manfaat dan nilai gizi kombucha, proses pembuatan kombucha serta aktivitas antioksidan minuman kombucha dari berbagai substrat seperti rosela, daun salam, daun jambu, daun sirih, daun sirsak, daun kopi, daun teh, bawang tiwai, teh hijau, teh oolong daun coklat, daun mangga dan daun tin. Diharapkan minuman kombucha dapat digunakan sebagai alternatif pangan fungsional yang dapat bermanfaat bagi kesehatan serta meningkatkan imun tubuh. 
Faktor Pembatas yang Mempengaruhi Pertumbuhan Mikroba

Faktor yang mempengaruhi

keberhasilan fermentasi pada proses

pembuatan kombucha antara lain koloni

SCOBY, gula, dan lingkungan.

Lingkungan yang optimal untuk

fermentasi adalah lingkungan udara dengan kadar oksigen rendah, suhu berkisar $20^{\circ}-23^{\circ} \mathrm{C}$ dan kelembaban yang tidak terlampau rendah (Naland, 2008). Keasaman juga mempengaruhi pertumbuhan mikroba, $\mathrm{pH}$ yang lebih tinggi dari 4,5 akan menciptakan lingkungan yang optimal bagi berkembangnya bakteri jahat (Mueller, 2014). Selain itu faktor lainnya adalah lama fermentasi. Lama fermentasi kombucha mempengaruhi kualitas fisik, kimia, dan sensori serta kesukaan kombucha. Fermentasi tersebut biasanya berlangsung selama 7-10 hari (Kapp, et.al., 2019) bahkan sampai 14 hari. Pada umumnya di daerah dengan suhu $22-26^{\circ} \mathrm{C}$ fermentasi berlangsung sekitar 4-6 hari (Wistiana dan Zubaidah, 2015). Fermentasi yang terlalu lama menyebabkan semakin tinggi kadar asam yang beresiko untuk dikonsumsi (Jayabalan, et al., 2014).

\section{Jenis Mikroba yang Berperan serta Senyawa yang Dihasilkan}

Kombucha merupakan minuman fermentasi antara teh dengan gula yang dilakukan oleh starter kultur kombucha yang disebut SCOBY (Symbiotic Culture of Bactery and Yeast) (Leal, et al., 2018). Kultur yang digunakan harus produktif yang ditandai dengan warna lebih cerah dan tidak rapuh ketika dipegang. Kultur yang tidak produktif berwarna coklat tua atau setelah melakukan fermentasi sekitar 5-7 kali (Simanjuntak, 2017).

Mikroorganisme yang berperan dalam proses fermentasi ini adalah golongan khamir, fungi dan bakteri yang bekerja secara simbiotik; seperti halnya golongan Acetobacter yaitu Acetobacter xylinum, Acetobacter aceti, Brettanomyces sp., Pichia sp., Saccharomyces sp., Zygosaccharomyces kombuchaensis, Torulopsis sp., Zygosaccharomyces bailii;

Schizosaccharomyces, Saccharomycodes, Torulaspora, Candida. Berikut ini penjelasan mengenai bakteri dan khamir yang terdapat pada SCOBY yaitu : (Watawana et.al., 2015; Crum dan Alex, 2016; Suhardini dan Zubaidah, 2016; Wulandari, 2018; Sievers etal., 1995). 


\section{Acetobacter}

Acetobacter merupakan strain bakteri bersifat aerobik yang menghasilkan asam asetat dan asam glukonat. Jenis Acetobacter yang biasa ditemukan dalam strain kombucha antara lain Acetobacter xylinum, Acetobacter xylinoides dan Acetobacter ketogenum.

\section{Saccharomyces}

Saccharomyces menghasilkan alkohol yang bisa bersifat aerobik atau anaerobik. Strain ini terdiri dari Saccharomyces ludwigii, Saccharomyces apiculatus, Schizosaccharomyces pombe, Zygosaccharomoyces dan Saccharomyces cereviseae.

\section{Brettanomyces}

Yang termasuk dalam strain ini adalah Brettanomyces bruxellensis dan Brettanomyces intermedius. Strain ini dapat bersifat sebagai aerobik atau anaerobik, dan dapat menghasilkan alkohol atau asam asetat

\section{Lactobacillus}

Lactobacillus dapat menghasilkan asam laktat dan lendir

\section{Prediococcus}

Bakteri ini bersifat anaerob, menghasilkan asam laktat dan lendir

\section{Gluconacetobacter Kombuchae}

Strain bakteri ini bersifat anaerob yang memakan nitrogen dan menghasilkan asam asetat dan asam glukonat.

\section{Zygosaccharomyces Kombuchaensis}

Strain yeast ini dapat menghasilkan alkohol dan karbonasi

Mikroorganisme dalam kombucha akan bermetabolisme terhadap gula sehingga menjadi berbagai jenis asam, alkohol dan vitamin yang berkhasiat bagi kesehatan (Falahuddin, et al., 2017). Komponen yang dihasilkan saat fermentasi antara lain etanol, asam asetat dan asam glukoronat, asam fenolat, asam laktat, vitamin B dan enzim. Pada kombucha terjadi dua jenis proses fermentasi yaitu fermentasi alkohol dan fermentasi asam asetat. Proses fermentasi diawali dengan pemecahan sukrosa menjadi glukosa dan fruktosa oleh aktivitas khamir yang memerlukan enzim invertase (Wulandari, 2018). Selanjutnya 
yeast mengubah glukosa hasil hidrolisis menjadi etanol dan $\mathrm{CO}_{2}$ kemudian bereaksi dengan air membentuk asam karbonat.

Tahap selanjutnya terjadi fermentasi alkohol yaitu khamir akan mendegradasi heksosa (glukosa, fruktosa) melalui glikolisis menjadi asam piruvat. Selanjutnya asam piruvat dikarboksilasi oleh enzim dekarboxilase piruvat menjadi asetaldehid dan $\mathrm{CO}_{2}$. Asetaldehid diubah menjadi etanol oleh enzim alkohol dehidrogenase (Mehta, et al., 2012) dalam Wulandari (2018). Setelah dihasilkan alkohol maka segera terjadi fermentasi asam asetat, bakteri asam asetat akan mengubah alkohol menjadi asam asetat secara aerob. Etanol diubah menjadi asetaldehid oleh enzim alkohol dehidrogenasi. Asetaldehid dioksidasi menjadi asetil KoA oleh enzim aldehid dehidrogenase. Selanjutnya asetil Koa diubah menjadi asetil-fosfat oleh enzim fosfotransasetilase. Asetil - fosfat mengalami defosforilasi menjadi asam asetat oleh enzim asetat kinase (Mehta etal., 2012) dalam Wulandari (2018).

Asam asetat merupakan produk dari proses fermentasi oleh Acetobacter. Selain itu Acetobacter dapat membentuk asam glukonat yang berasal dari oksidasi glukosa. Bakteri asam asetat memanfaatkan etanol untuk memproduksi asam asetat. Adanya asam asetat menstimulasi khamir untuk memproduksi etanol. Glukosa dan fruktosa dipecah menjadi asam-asam organik dan alkohol secara terus menerus sampai gula yang terdapat pada larutan kombucha habis; sehingga asam yang dihasilkan akan terus meningkat seiring dengan lamanya fermentasi (Simanjuntak, et al., 2016).

\section{Manfaat dan Nilai Gizi Kombucha}

Kombucha mempunyai rasa asam dan menyegarkan akibat proses fermentasi. Saat proses fermentasi kombucha dihasilkan senyawa seperti polifenol, asam organik (asam asetat, asam glukoronat, dll), vitamin, asam folat, asam amino esensial, antibiotik dan enzim yang bermanfaat bagi kesehatan. Enzim merupakan senyawa organik yang berperan memperlancar metabolisme zatzat dalam tubuh (Miranda, et al., 2016). Berdasarkan penelitian Zubaidah, et.al. (2018a) kombucha dapat digunakan sebagai agen terapi bagi penderita diabetes. Lebih lanjut Zubaidah et.al (2019) menyampaikan bahwa kombucha 
yang berasal dari buah salak lebih baik daripada kombucha dari teh hitam.

Keunggulan teh kombucha dibandingkan dengan minuman teh biasa yaitu lebih banyak kandungan asam organik vitamin dan asam amino (Purnami, et al., 2018). Manfaat kombucha bagi tubuh sebagai antioksidan dan antidiabetik, antibakteri, memperbaiki mikroflora usus, meningkatkan ketahanan tubuh dan menurunkan tekanan darah, menurunkan kolesterol, mencegah penyakit kardiovaskular, mengurangi inflamasi, dan mestimulasi sistem imun tubuh (Villarreal-Soto, et al., 2018; Zubaidah, et al.,2018a, 2018b, 2019). Kombucha juga mampu melancarkan pencernaan dan sebagai antibiotik (Chen and Chu, 2006). Kombucha juga dapat mengobati pembengkakan dubur, rematik dan encok pada persendian, menjaga kesehatan hati, mencegah kanker, mengobati sembelit serta sakit kepala (Naland 2004).

\section{Senyawa-Senyawa yang Terkadung dalam Kombucha}

\section{Polifenol}

Polifenol yang paling banyak
ditemukan pada kombucha adalah

epicatechin (EC), epigallocatechin (EGC), epicatechin gallate (ECG), dan epigallocatechin gallate (EGCG) (Manach, et.al., 2004). Sifat antioksidan polifenol bertanggung jawab atas efek kesehatan seperti pencegahan kanker, peningkatan kekebalan, pereda inflamasi dan radang sendi (Jayabalan, et al., 2014). Berdasarkan hal tersebut, maka aktivitas antioksidan pada kombucha terutama dikaitkan dengan polifenol yang diproduksi selama fermentasi dan efek sinergis dari berbagai senyawa yang ditemukan dalam teh (Jayabalan, et al., 2008). Polifenol juga berperan sebagai antikanker dengan mekanisme sebagai berikut: (1) penghambatan mutasi genetik; (2) penghambatan proliferasi sel kanker; (3) induksi apoptosis sel kanker; dan (4) metastasis (Park and Dong, 2003).

\section{Asam organik}

Asam organik yang terbentuk saat fermentasi kombucha antara lain asam asetat, asam glukonat, asam glukoronat, asam folat, asam malonat, asam oksalat, asam piruvat, asam laktat, asam malat, asam sitrat dan tartarat yang mempunyai efek sebagai antibakteri dan mencegah kontaminasi kombucha dari bakteri 
pathogen (Jayabalan, et al., 2014; NeffeSkocinska, et al., 2017).

Asam asetat merupakan senyawa kimia yang bertanggung jawab atas aroma asam dan rasa seperti cuka pada kombucha. Konsentrasinya cenderung meningkat, mencapai $11 \mathrm{~g} / \mathrm{l}$ setelah fermentasi selama 30 hari dan secara bertahap menurun hingga $8 \mathrm{~g} / \mathrm{l}$ setelah fermentasi selama 60 hari. Penurunan ini karena bakteri menggunakan asam asetat sebagai sumber karbon ketika cadangan gula dan etanol sudah habis (Leal dkk., 2018 ).

Asam glucoronate bertindak sebagai senyawa pendetoksi dalam tubuh karena mengikat senyawa beracun yang ada di hati, memungkinkan zat ini dikeluarkan oleh ginjal dengan lebih efisien selain menjadi prekursor dalam biosintesis vitamin C (Nguyen dkk., 2015).

\section{Vitamin dan Mineral}

Menurut Leal, et al. (2018), kombucha juga mengandung vitamin dan mineral. Vitamin yang terkandung dalam kombucha antara lain vitamin B1, B2, B6, B12 dan C. Mineral dalam kombucha meliputi mangan, besi, nikel, tembaga, seng, timbal, kobalt, kromium dan cadmium serta mengandung anion yaitu fluorida, klorida, bromida, iodida, nitrat, fosfat dan sulfat (Leal, et.al., 2018).

\section{Proses Pembuatan Kombucha}

Bahan utama yang digunakan membuat minuman kombucha yaitu media (substrat), gula dan kultur kombucha yang berupa nata (SCOBY) dan baby kombucha yang berupa kombucha cair. Media yang biasa digunakan yaitu daun teh Camellia sinensis, tetapi sebenarnya dapat menggunakan bahan lain yang mengandung senyawa bioaktif tinggi.

Tahap pertama adalah membuat media terlebih dahulu, yaitu daun teh yang masih muda, yang berpotensi mengandung senyawa bioaktif (3-5 daun dari pucuk). Pada umumnya untuk membuat 1 liter kombucha diperlukan 1215 gr sendok dedaunan kering (Sutarmi, 2005). Dedaunan teh direbus pada $80^{\circ} \mathrm{C}$ selama 15 menit, dan ditambahkan gula pasir sebanyak 10\%-20\% (b/v) dari larutan, kemudian disaring dan dimasukkan ke dalam toples kaca supaya asam organik tidak bereaksi dengan wadah. Setelah itu didinginkan hingga 
mencapai suhu $25^{\circ} \mathrm{C}$. Waktu pendinginan tidak boleh lebih dari 4 jam. Sebelum 4 jam, kemudian ditambahkan starter kombucha cair sebanyak $10 \% \mathrm{v} / \mathrm{v}$ dari larutan dan kultur padat (SCOBY) sebanyak $11 \%$ b/v. Jar kaca ditutup menggunakan kain putih bersih dan diikat karet lalu difermentasi pada suhu ruang selama 6-14 hari (lama fermentasi tergantung jenis daun yang digunakan) dan tidak boleh terkena sinar matahari. Setelah fermentasi, dilakukan pemisahan minuman teh kombucha dengan starter kombucha. Minuman kombucha segera dikemas dan ditutup rapat.

Selama waktu fermentasi akan terbentuk polisakarida yaitu selulosa. Selulosa tersebut membentuk benang serat yang terus menebal membentuk jaringan kuat yang disebut pelikel nata. Keberhasilan proses fermentasi ditandai dengan terbentuknya koloni bakteri dan khamir yang mengapung di atas permukaan larutan kombucha (Nainggolan, 2009).

\section{Aktivitas Antioksidan dan Potensi Pangan Fungsional}

$\begin{array}{crr}\text { Saat } & \text { fermentasi } & \text { khamir } \\ \text { menghasilkan } & \text { enzim } & \text { vinyl }\end{array}$

phenol reductase, bersama dengan enzim ferulic acid reductase akan membentuk fenol akibat dekarboksilasi asam sinamat dan asam firulat. Asam sinamat merupakan senyawa fenol yang berfungsi sebagai antioksidan alami sedangkan asam ferulat merupakan turunan dari golongan asam hidroksi sinamat, yang merupakan senyawa aktif dan bersifat antioksidan (Kunaepah, 2008; Suranto, 2011; Hasan, et al., 2013; Suhardini dan Zubaidah, 2016).

Berbagai jenis dedaunan yang mengandung senyawa bioaktif tinggi seperti daun jambu biji mengandung antioksidan, tannin, polifenolat, flavonoid, monoterpenoid, siskulterpen, alkaloid, kuinon, saponin, karoten dan eugenol dapat digunakan sebagai media fermentsi Kombucha (Kurniawati, 2006). Daun kopi mengandung antioksidan, alkaloida, saponin, flavonoid dan polifenol. Daun sirsak mengandung antioksidan (Leny, 2006). Daun salam mengandung tannin, minyak atsiri, seskuiterpen, triterpenoid, fenol, steroid, sitral, lakton dan saponin (BPOM, 2004). Daun sirih mampu untuk menghilangkan senyawa nyeri sehingga disebut sebagai obat analgetik (Karlisna, 2010). Pada 
penelitian tersebut dihasilkan bahwa selama fermentasi terjadi peningkatan senyawa fenol dengan konsentrasi yang berbeda untuk setiap jenis daun. Semakin tinggi senyawa fenolik yang dihasilkan maka semakin tinggi pula aktivitas antioksidannya, hal ini dibuktikan dengan terjadi kenaikan aktivitas antioksidan selama fermentasi hingga hari ke-8 dan terjadi penurunan hingga hari ke-14. Penurunan terjadi karena suasana asam menyebabkan senyawa fenolik menjadi semakin stabil dan sulit melepaskan proton yang dapat berikatan dengan DPPH sehingga aktivitas antioksidannya menurun (Ayu, 2013). Di antara daun salam, daun jambu, daun sirih, daun sirsak, daun kopi Robusta, dan daun teh yang digunakan untuk membuat kombucha, diperoleh perlakuan terbaik dengan lama fermentasi selama 8 hari didapatkan pada kombucha daun teh (0.23\%) dengan total asam $0.09 \%, \mathrm{pH}$ 2.84, aktivitas antioksidan $92.97 \%$, total fenol sebesar $303.05 \mu \mathrm{g} / \mathrm{ml}$ GAE, total gula $2.86 \%$, ketebalan nata $0.45 \mathrm{~mm}$.

Menurut Suhartatik, et al., (2019) kombucha rosella akan mengalami penurunan aktivitas antioksidannya meskipun sangat kecil daripada kombucha dari daun teh (Camellia sinensis). Aktivitas antioksidan kombucha rosella tergolong tinggi dibandingkan dengan daun teh (turun sebanyak $85 \%$ setelah difermentasi selama 10 hari). Besarnya aktivitas antioksidan dinyatakan sebagai prosentase jumlah radikal bebas yang mampu ditangkap oleh senyawa antioksidan. Semakin besar nilai yang tertera maka semakin besar pula aktivitas antioksidannya. Antioksidan yang terdapat pada kombucha rosella berasal dari antosianin yang merupakan pigmen tumbuhan. Antosianin mampu menghambat sel kanker HL-60 dengan dosis $0-4 \mathrm{mg} / \mathrm{ml}$ rosella. Selain itu antosianin mampu menyerap toksin serta kolesterol yang ada dalam saluran pencernaan serta membuangnya melalui sistem ekskresi. Kolesterol dapat berkurang ssebesar $56 \%$ setelah mengkonsumsi kombucha. Dari hasil penelitian diperoleh bahwa aktivitas antioksidan kombucha rosella dengan kadar rosella kering $40 \mathrm{~g} / \mathrm{L}$ dan $50 \mathrm{~g} / \mathrm{L}$ cenderung tidak berbeda nyata. Perlakuan terbaik diperoleh pada kombucha rosella 40g/L dengan lama fermentasi 5 hari, berdasarkan aktivitas antioksidannya 
selain itu juga lebih efektif dalam menurunkan kolesterol darah tikus yang menderita hiperkolesterolemia daripada kombucha dari teh hitam dan perlakuan placebo.

Yasmina, et al. (2016) menyatakan bahwa aktivitas antioksidan kombucha bawang tiwai selama fermentasi pada pengamatan hari ke-8 sebesar 73,97\% sedangkan fermentasi hari ke-14 berkisar $83,52 \%$. Nilai aktivitas antioksidan kombucha pasak bumi selama fermentasi pada pengamatan hari ke-8 dan dari ke-14 secara berurutan 59,44\% dan 57,51\%. Menurut Yasmina, et.al. (2016) perlakuan terbaik terdapat pada kombucha bawang tiwai dibandingkan dengan kombucha pasak bumi, terjadi pada fermentasi hari ke-14, dengan nilai aktivitas antioksidan $83,52 \%$ dan nilai IC50 0,2\%.

Hassmy, et al., (2017) menyatakan bahwa pada pembuatan kombucha teh hijau dilakukan dengan memasukkan 5 kantung teh seduhan celup (8 gram) ke dalam air $1500 \mathrm{ml}$ dengan gula 15\%, maka diperoleh aktivitas antioksidan teh hijau kombucha yang optimal pada hari ke-1 sampai ke-5 dengan nilai 90,835 \% 91,853\%. Nilai aktivitas antioksidan teh hijau kombucha mengalami penurunan setelah hari ke-15. Sedangkan aktivitas antioksidan pada kombucha teh daun coklat dengan waktu fermentasi selama 14 hari sebesar 87,745\% (Hidayana dan Kusuma, 2017).

Menurut Khaerah dan Akbar (2019) nilai IC50 kombucha teh hijau sebesar 19,76-22, $74 \mu \mathrm{g} / \mathrm{ml}$, kombucha teh putih nilai IC50 21,96-23,71 $\mu \mathrm{g} / \mathrm{ml}$, kombucha teh hitam 61,39-62,17 $\mu \mathrm{g} / \mathrm{ml}$, sedangkan kombucha teh oolong 48,68-51,07 $\mu \mathrm{g} / \mathrm{ml}$. Dari data terlihat bahwa nilai IC50 terendah terdapat pada kombucha teh hijau, sedangkan nilai IC50 tertinggi terdapat pada kombucha teh hitam.

Pada penelitian terlihat bahwa aktivitas antioksidan kombucha tertinggi terdapat pada kombucha teh daun manga dengan fermentasi selama 12 hari, yaitu $89,29 \%$ (Sari, 2014). Sedangkan penelitian yang dilakukan oleh Sutarmi, (2005) mengenai kombucha probiotik yang menggunakan bakteri BAL $L$. plantarum pi28a dan L. coryneformis tpyk pada teh hijau dan teh oolong, diperoleh hasil bahwa L. plantarum pi28a mampu tumbuh lebih baik di dalam teh oolong dan teh hijau manis dibandingkan L. coryneformis tpyk. L. plantarum pi28a mempunyai kemampuan untuk tumbuh 
lebih baik di dalam kombucha teh oolong daripada kombucha teh hijau. Perlakuan kombucha teh oolong baik yang kontrol maupun yang diberi perlakuan bakteri BAL serta teh oolong manis dengan penambahan bakteri BAL mampu menurunkan E. coli sebanyak 4.08-4.26 $\log \mathrm{CFU} / \mathrm{ml}$. Pada kontrol teh oolong manis tanpa BAL jumlah $E$. coli mengalami kenaikan sebesar $3.86 \mathrm{log}$ CFU/ml. Pada kombucha teh hijau dengan penambahan BAL maupun kontrol kombucha teh hijau serta teh hijau manis dengan penambahan BAL mampu menurunkan E. coli sebesar 3.94-4.65 log CFU/ml sedangkan pada kontrol teh hijau manis tanpa BAL mengalami kenaikan sebesar $3.48 \log \mathrm{CFU} / \mathrm{ml}$. Teh hijau kombucha probiotik dan teh hijau manis probiotik juga mampu menurunkan $S$. aureus sebesar 2.92-3.34 log CFU/ml sedangkan pada kontrol teh hijau kombucha hanya sebesar 0.59-1.21 log $\mathrm{CFU} / \mathrm{ml}$. Pada kontrol teh hijau manis terjadi kenaikan S.aureus sebesar $0.55 \log$ CFU/ml. Pengamatan terhadap penyimpanan kombucha teh oolong probiotik selama empat minggu pada suhu lemari es $\left(3-5^{\circ} \mathrm{C}\right)$ menunjukkan viabilitas BAL yang masih cukup stabil sebesar $7.09 \log \mathrm{CFU} / \mathrm{ml}$.

Kombucha daun tin juga berpotensi sebagai antimikroba terutama sebagai antibakteri seperti halnya yang dilakukan oleh Novitasari dan Wijayanti (2018) bahwa dari hasil pengujian diperoleh rerata zona hambat terhadap Escherichia coli 6,97 mm, Staphylococcus aureus 5,5 $\mathrm{mm}$, Lactobacillus casei $5,29 \mathrm{~mm}$, dan Candida albicans $0,37 \mathrm{~mm}$.

\section{Potensi Minuman Kombucha sebagai Pangan Fungsional}

Kombucha dapat digunakan sebagai alternatif pangan fungsional. Selama fermentasi, mikroorganisme melakukan metabolisme dengan memanfaatkan enzim pada sel tanaman untuk mengubah kelompok fungsional senyawa kimia yang terdapat di dalamnya. Senyawa yang dihasilkan di antaranya adalah fenolik bebas yang semakin meningkat seiring dengan lamanya fermentasi. (Suhardini dan Zubaidah, 2016).

Antioksidan mempunyai kemampuan menghambat oksidasi dengan mengikat radikal bebas dan molekul yang sangat reaktif (partikel berbahaya yang terbentuk sebagai hasil 
samping proses metabolisme, dapat merusak materi genetik dan merusak sistem kekebalan tubuh), menghambat pertumbuhan sel kanker dan mengurangi penimbunan kolesterol dalam darah dan mempercepat pembuangan kolesterol melalui feses (Puspitasari, et al.,2017; Hidayana dan Kusuma, 2017).

Mikroba dalam kombucha merubah larutan teh dan gula menjadi berbagai senyawa lain yang berkhasiat yaitu berbagai jenis asam organik (asam asetat, asam sitrat, asam malat, asam glukoronat, asam laktat, asam kaprilat, asam karbonat, asam folat, asam glukonat, asam condroitin sulfat, asam hyaluronic dan asam usnat), asam amino, vitamin (B1, B2, B3, B6, B12, B15 dan C) serta polifenol yang memiliki efek antioksidan kuat (Naland, 2004; Sieversa etal., 1995). Asam-asam organik tersebut mempunyai manfaat bagi metabolisme tubuh sehingga berpotensi sebagai antibiotik alami (Rofiq, 2002). Selain itu kombucha dapat membuang toksin dalam tubuh. Senyawa yang berperan sebagai detoksifier dalam kombucha adalah asam glukoronat yang membuang substansi yang tidak dibutuhkan oleh tubuh seperti kolesterol dan deposit racun dalam liver. Selain asam glukoronat, juga dihasilkan asam organik seperti asam asetat yang mempunyai kemampuan untuk konjugasi toksin, dan merubahnya menjadi senyawa yang lebih larut untuk dikeluarkan dari tubuh (Yasmina etal., 2016).

Berbagai literatur menyebutukan kandungan senyawa kimia pada minuman kombucha berbeda-beda, karena bahan baku media yang digunakan berbeda, kandungan senyawa bioaktifnya juga berbeda, waktu fermentasi, konsentrasi gula serta asal dan komposisi kultur kombucha yang berbeda.

Kombucha juga mempunyai kemampuan sebagai immunomodulator yang dapat meningkatkan sistem imun, hal ini terbukti pada penelitian mengenai kombucha oak yang menunjukkan aktivitas antioksidan karena komponen fenoliknya. Komponen fenolik yang terdapat pada kombucha oak memiliki kemampuan imunomodulator dengan menekan produksi NO, TNF- $\alpha$, dan IL-6 yang diinduksi oleh LPS (VázquezCabral etal., 2017).

\section{Efek Negatif Kombucha}

Berdasarkan uraian di atas, dapat diketahui bahwa kombucha mempunyai 
efek penting bagi kesehatan. Tetapi tidak dianjurkan untuk mengkonsumsi teh kombucha yang mengalami fermentasi yang terlalu lama. Hal ini disebabkan peningkatan asam organik seiring dengan lamanya waktu fermentasi. Chu dan Chen (2006) menyatakan bahwa kandungan total polifenol meningkat secara linier selama fermentasi. Semakin lama fermentasi, semakin meningkat pula asam organik yang berbahaya jika dikonsumsi secara langsung (Jayabalan, et al., 2008 ).

Efek negatif yang dilaporkan setelah mengkonsumsi kombucha antara lain pusing, mual, reaksi alergi, lactic acidosis dan hipertermia. Gejala tersebut dijumpai jika mengkonsumsi kombucha secara berlebih, kurang higienis pada saat preparasi dan pengolahan kombucha, kondisi kesehatan konsumen (mempunyai sistem imun yang rendah misalnya karena HIV atau gagal ginjal akut), peristiwa leaching logam berat dari wadah yang digunakan untuk proses pengolahan (Jayabalan, et.al., 2014; Leal, et.al., 2018; Coelho, et.al., 2020).

\section{Kesimpulan}

Minuman kombucha sangat berpotensial sebagai pangan fungsional.

\section{DAFTAR PUSTAKA}

Ayu S, R. Yan, L. Eka. 2013. Penetapan Antioksidan pada Teh Hitam Kombucha Lokal di Bali dengan Waktu Fermentasi. Bali: Universitas Udayana.

Chu, S.C., C. Chen. 2006. Effects of Origins and Fermentation Time on the Antioxidant Activities of Kombucha. Food Chem. $98 \quad$ (3): 502-507. https://doi.org/10.1016/j. foodchem.2005.05.080.

Coelho,R,M,D., A.L de Almeida; R. Q. G do Amaral; R. N da Mota dan P. H. $M$ de Sousa. 2020. Kombucha. International Journal of Gastronomy and Food Science. 22 100272. https://doi.org/10.1016/j.ijgfs.2020. 100272.

Crum, H. dan A. LaGory. 2016. The Big Book of Kombucha: Brewing, Flavoring and Enjoying The Health Benefits of Fermented Tea. USA : Storey Publishing.

Falahuddin, I., I. Apriani dan Nurfadilah . 2017. Pengaruh Proses Fermentasi Kombucha Daun Sirsak (Annona muricata L.) terhadap Kadar Vitamin C. Jurnal Biota. 3 (2): 90105.

Hasan A.E.Z, D. Mangunwidjaja, T.C Sunarti1, O. Suparno, A. Setiyono. 2013. Optimasi Ekstraksi Propolis Menggunakan Cara Maserasi dengan Pelarut Etanol $70 \%$ dan Pemanasan Gelombang 
Mikro Serta Karakteristiknya sebagai Bahan

Antianker Payudara. Institut Pertanian Bogor. Bogor.

Hassmy, N.P., J. Abidjulu dan A. Yudistira. 2017. Analisis Aktivitas Antioksidan pada Teh Hijau Kombucha Berdasarkan Waktu Fermentasi yang Optimal. Pharmacon Jurnal Ilmiah Farmasi Unsrat. 6 (4): 67-74.

Hidayana, V dan A. E. Kusuma. 2017. Uji Aktivitas Antioksidan Teh Kombucha Daun Coklat (Theobroma cacao. L) Berdasarkan Lama Fermentasi. Jurnal Farmasi Higea. 9 (2): 103-108.

Jayabalan, R., P. Subathradevi, S. Marimuthu, M. Sathishkumar, K. Swaminathan.

2008. Changes in Free-Radical Scavenging Ability of Kombucha Tea During Fermentation. Food Chem. 109 (1): 227-234. https://doi.org/10.1016/j. foodchem.2007.12.037.

Jayabalan, R., R.V. Malbasa, E.S. Loncar, J.S. Vitas, M. Sathishkumar. 2014. A Review on Kombucha TeaMicrobiology, Composition, Fermentation, Beneficial Effects, Toxicity and Tea Fungus. Comprehensive Reviews in Food Science and Food Safety. 13 (4) : 538:550.

https://doi.org/10.1111/15414337.12073.

Karlisna, Y.P. 2010. Pengaruh Ekstrak Daun Sirih terhadap Jumlah Geliat Mencit BALB/C yang Diinduksi
Asam Asetat. Universitas Diponegoro. Semarang.

Kapp, J.M., FACCE, Sumner. 2019. Kombucha: a Systematic Review of The Empirical Evidence of Human Health Benefit. Annals of Epidemiology Journal. 30 (2019). 66-70.

Khaerah, A dan F. Akbar. 2019. Aktivitas Antioksidan Teh Kombucha dari Beberapa Varian Teh yang Berbeda. Prosiding Seminar Nasional LP2M UNM - 2019 "Peran Penelitian dalam Menunjang Percepatan Pembangunan Berkelanjutan di Indonesia" ISBN: 978-623-7496-14-4. Hal 472-476

Kunaepah, U. 2008. Pengaruh Lama Fermentasi dan Konsentrasi Glukosa terhadap Aktivitas Antibakteri, Polifenol Total dan Mutu Kimia Kefir Susu kacang Merah. Tesis Magister Gizi Masyarakat. UNDIP. Semarang.

Kurniawati, A. 2006. Formulasi Gel Antioksidan Ekstrak Daun jambu Biji (Psidium guajava L) dengan Menggunakan Aquapec HV-505. Skripsi. Jurusan Farmasi FMIPA Unpad. Bandung.

Leal, M., V. Suarez, R. Jayabalan, H. Oros, A. Escarlante-aburto, 2018. A review on Health Benefits of Kombucha Nutritional Compounds and Metabolites. CYTA - J. Food $16 \quad$ (1), 390-399. https://doi.org/10.1080/19476337.2 $\underline{017.1410499 .}$. 
Leny, S. 2006. Senyawa Flavonoida, Fenilpropanoida dan Alkaloida. Sumatera Utara: USU Repository.

Manach, C., A. Scalbert, C. Morand, C., $\mathrm{R}^{\prime}$ em' esy, L. Jim 'enez. 2004. Polyphenols: Food Sources and Bioavailability. Am. J. Clin. Nutr. 79 (5): 727-747. https://doi.org/ 10.1093/ajcn/79.5.727.

Mehta, B., M. Afaf Kamal-Edin, R. Z. Iwanski. 2012. Fermentation Effects on Food Properties. Boca Raton. United States. CRC Press Taylor \& Francis Group.

Miranda B, N.M. Lawton, S.R. Tachibana, N.A. Swartz, W.P. Hall. Titration and HPLC Characterization of Kombucha Fermentation: a Laboratory Experiment in Food Analysis. J Chem Educ 2016; 93(10):1770-5.

Mueller, J. 2014. Delicious Probiotics Drinks. Skyhorse Publishing. New York.

Nainggolan, J. 2009. Kajian Pertumbuhan Bakteri Acetobacter sp. dalam Kombucha Rosela Merah (Hibiscus Sabdariffa) pada Kadar Gula dan Lama Fermentasi yang Berbeda. Tesis. Universitas Sumatra Utara: Medan.

Naland, H. 2004. Kombucha Teh Ajaib Pencegah dan Penyembuh Aneka Penyakit. PT Agro Media Pustaka. Jakarta.
Naland H. 2008. Kombucha: Teh dengan Seribu Khasiat. Jakarta: Agromedia.

Neffe-Skocinska, K., B. Sionek, I. Scibisz, D. Kolozyn-krajewska. 2017. Acid Contents and the Effect of Fermentation Condition of Kombucha Tea Beverages on Physicochemical, Microbiological and Sensory Properties. CyTA - J. Food 15 601-607. https://doi.org/10.1080/19476337.2 017.1321588.

Nguyen, K.N., P.B. Nguyen, H.T. Nguyen, P.H. Le. 2015. Screening the Optimal Ratio of Symbiosis Between Isolated Yeast and Acetic Bacteria Strain from Traditional Kombucha for HighLevel Production of Glucuronic Acid. LWT-Food Science and Technology. 64 (2): 1149-1155. https://doi.org/10.1016/j.lwt.2015.0 7.018 .

Novitasari, E.D dan E.D. Wijayanti. 2018. Aktivitas Antimikroba Teh Asam Daun Tin (Ficus carica) secara in Vitro. Journal Cis-Trans (JC-T). 2 (2): 25-29.

Park, A., Z. Dong. 2003. Signal Transduction Pathways: Targets for Green And Black Tea Polyphenols. J. Biochem. Mol. Biol. $\quad 36$ (1): 66-77. https://doi.org/10.5483/ BMBRep.2003.36.1.066.

Purnami, K.I., A.A.G.N.A. Jambe., N.W. Wisaniyasa. 2018. Pengaruh Jenis Teh terhadap Karakteristik Teh Kombucha. Jurnal Itepa. 7 (2): 110. 
Puspitasari, Y., R. Palupi, dan M. Nurikasari. 2017. Analisis Kandungan Vitamin C Teh Kombucha Berdasarkan Lama Fermentasi Sebagai Alternatif Minuman Untuk Antioksidan. Global Health Science. 2 (3): 245253.

Rofiq, M. N. 2002. Pengaruh Inhibisi Teh Fermentasi Kombucha terhadap Bakteri Salmonella pullorum secara in Vitro. Jurnal Sains dan Teknologi Indonesia. 4 (5): 186189.

Sari, N., 2014. Perbandingan Aktivitas Antioksidan Kombucha Teh hijau (Camelia sinensis) dengan Teh Daun Mangga (Mangifera indica) Dipengaruhi Lama Fermentasi, Program Studi Pendidikan Biologi, Skripsi, Fakultas Keguruan Dan Ilmu Pendidikan, Universitas Muhammadiyah, Surakarta.

Sieversa M, C. Lanini, A. Weber, U. Schuler-Schmid, M. Teuber. 1995. Microbiology and Fermentation Balance in a Kombucha Beverage Obtained from a Tea Fungus Fermentation. Systematic and Applied Microbiology. 18(4):590594.

Simanjuntak, D.H, Herpandi dan S.D. Lestari. 2016. Karakteristik Kimia dan Aktivitas Antioksidan Kombucha dari Tumbuhan Apu-apu (Pistia stratiotes) selama Fermentasi. Fishtech. Jurnal Teknologi Hasil Perikanan. 5 (2) : 123-133.
Simanjuntak, R. J.D. 2017. Efek Antibakteri Kopi Robusta yang Difermentasi dengan Kombucha terhadap Salmonella Typhi. Skripsi. Universitas Lampung.

Suhardini, P.N dan E. Zubaidah, E. 2016. Studi Aktivitas Antioksidan Kombucha dari Berbagai Jenis Daun Selama Fermentasi. Jurnal Pangan dan Agroindustri. 4 (1): 221-229.

Suhartatik, S., M. Karyantina dan I.T. Purwanti. 2019. Kombucha Rosella (Hibiscus sabdariffa Linn) dan Kemampuannya sebagai Antihiperkolesterolemia. Agritech. 29 (1): 29-35.

Suranto, A. 2011. Dahsyatnya Sirsak Tumpas Penyakit. Pustaka Bunda, Jakarta.

Sutarmi, M. 2005. Pengembangan Produk Kombucha Probiotik Berbahan Baku Teh Hijau dan Teh Oolong. Skripsi. Fakultas Teknologi Pertanian. Institut Pertanian Bogor. Bogor.

Vázquez-Cabral, B. D., M. Larrosa-Pérez, J.A. Gallegos-Infante, M.R. Moreno-Jiménez, R.F. González-Laredo, J.G. RutiagaQuiñones \& N.E. Rocha-Guzmán. 2017.

Oak Kombucha Protects Against Oxidative Stress and Inflammatory processes. Chemico-Biological interactions, 272, 1-9.

Villarreal-Soto, S.A., S. Beaufort, J. Bouajila, J.P. Souchard, P. Taillandier. Under-Standing 
Kombucha Tea Fermentation: a Review. J Food Sci 2018; 83(3):580-8.

Watawana, M.I., N. Jayawardena, C.B. Gunawardhana, V.Y. Waisundara. 2015. Health, Wellness, and Safety Aspects of the Consumption of Kombucha. J Chem.

Wistiana, D. Dan E. Zubaidah. 2015. Karakteristik Kimiawi dan Mikrobiologis Kombucha dari Berbagai Daun Tinggi Fenol Selama Fermentasi. Jurnal Pangan dan Agroindustri. 3 (4): 1446-1457.

Wulandari, A. 2018. Pengaruh Lama Waktu Fermentasi Kombucha Teh Hijau Daun Jati (Tectona grandis) terhadap Kadar Tanin Total dan Total Asam Tertitrasi (TAT). Skripsi. Universitas Sanata Dharma. Yogyakarta.

Yasmina, K.V., W.C. Prabowo dan R. Rusli. 2016. Uji Aktivitas Antioksidan Kombucha Bawang Tiwai (Eleutherine palmifolia) dan Kombucha Pasak Bumi (Eurycoma longifolia jack). Prosiding Seminar Nasional Kefarmasian ke-4. Samarinda, Oktober. Hal. 175 179.

Zubaidah, E., F.J. Dewantari, F.R. Novitasari, I. Srianta, P.J. Blanc. 2018a. Potential of Snake Fruit (Salacca zalacca (Gaerth.) Voss) for The Development of a Beverage Through Fermentation with the Kombucha Consortium. Biocatal. Agric. Biotechnol. 13: 198-203.
Zubaidah, E., T.E. Apriyadi, U. Kalsum, E. Widyastuti, T. Estiasih, I. Srianta P.J. Blanc. 2018b. In Vivo Evaluation of Snake Fruit Kombucha as Hyperglycemia Therapeutic Agent. Int. Food Res. J. 25 (1): 453-457.

Zubaidah, E., C.A. Afgani., U. Kalsum, I. Srianta, J B. Philippe. 2019. Comparison of in Vivo Antidiabetes Activity of Snake Fruit Kombucha, Black Tea Kombucha and Metformin. Biocatalysis and Agricultural Biotechnology. 17: 465-469. 